\title{
REVIEWS.
}

\section{GENITAL ABNORMALITIES, HERMAPHRODITISM AND RELATED ADRENAL DISEASES.}

By Hugh Hampton Young, M.A., M.D., Sc.D., F.R.C.S.I., D.S.M. London. Baillière, Tindall and Cox. 1937. Price 45s.

This sumptuous volume is the work of the distinguished Professor of Urology at the Johns Hopkins University, aided, as we learn from the Preface, by a number of confrères. It opens with a chapter on hermaphroditism in literature and art by Professor D. M. Robinson, of the Chair of Archæology, and Dr. L. Edelstein, Associate in the History of Medicine at the Johns Hopkins University. Their contribution which is necessarily compressed is illustrated by many plates, not a few of them of peculiar interest, and makes a useful introduction to the lore of the subject. It is followed by a chapter on the embryology of the genital system, in which the early close relationship between adrenal and sex glands is referred to, and the masculinizing effect of adrenal tumours on the female.

Hermaphroditism has become the subject of a complicated nomenclature. In the classical sense hermaphroditism is characterized by the presence of gonads, and of external genitalia, of both sexes in the individual. It is remarked that " no such perfect hermaphrodite has been scientifically proven to have existed " in man. In practice we may separate hermaphrodites into two classes according as they are examples of true or false hermaphrodism. The "true" hermaphrodites are of three varieties: (1) lateral, with ovary on one side and testicle on the other; (2) unilateral, having both ovary and testicle on one side, and one gonad on the other; and (3) bilateral, in which ovary and testicle are found on both sides.

While such hermaphroditismus verus is very rare, pseudohermaphroditismus would appear to be distinctly less uncommon (1 in 1,000 persons). It is characterized by the presence of gonads of one sex, associated with external genitalia of doubtful sex; but in many of the cases the secondary sex- characters are those of the opposite sex. In such cases, usually, a male is mistaken for a female. The author employs a simple nomenclature: if the gonads are testes the patient is termed a male, if ovaries, a female, pseudohermaphrodite. It is noted that in the latter enlarged adrenals are not uncommon. Very full clinical histories are given of 8 male and 4 female cases; also of 4 cases in which the sex was undetermined. These last he speaks of as "practising hermaphrodites," a term which will clearly be understood on referring to their histories! Only one case is reported here of hermaphroditismus verus: it was of the "lateral" type. In addition to the author's personal cases there is a fairly full review of the literature.

The " adreno-genital syndrome" is next dealt with. Apert's view is quoted, to the effect that when the lesion in adrenal begins in embryonic life, the result is female pseudohermaphrodism, i.e., feminine internal and masculine external organs. The adrenal arising close to the genital ridge ofo the embryo it has been suggested that the? male elements of the ovary may occasionally become incorporated in the neighbouring adrenal cortex, run wild there, and give rise to hyperplasia or neoplasms. Arising from the male tissue of the genital ridge these cells give rise to internal secretion causing development of male sexual characteristics. Reference is made to Grollman's " androgenic " tissue in the adrenal, developing in fœetal life and normally disappearing during the first year of life.

The author rightly emphasizes pelvic exploration by laparotomy in all cases. $\mathrm{He}$ also describes the technique of his operation for the exposure of the adrenals. Full details likewise are given of plastic operations to make external genitalia conform to the anatomical, if not to physiological, type.

The subject of arrhenoblastoma is fairly fully reviewed, and there follows a consideration of malformations of external genitals, ectopia vesicæ, cryptorchidism, and atresia ani. The concluding chapter deals with endocrine thetapy.

The volume contains much original work and shows also considerable familiarity with the work of others. Occasionally we have 
found difficulty in rapidly grasping the author's meaning. The text might in places have been made a little clearer, and a little more conciseness would not have lessened its value.

The work is freely illustrated by plates from drawings by Wm. P. Didusch. They are beautifully executed and have marginal legends furnished with indicators to the different parts referred to. This arrangement saves the reader all difficulty in identifying the parts referred to in the text. The book is a valuable one and, besides acting as a reference-volume, will repay careful reading. The author is to be congratulated on his presentment of the subject and the printers and publishers on the way in which they have produced the work.

\section{Miscellaneous.}

This Section deals with New Drugs, Preparations, Surgical Instruments, etc. The description of each article is supplied by the Producer. Particulars regarding insertions, which are free of cost, may be obtained from the Business Manager, Fellowsin of Medicine and Post-Graduate Journal, 404, Grand Buildings, W.C.2.

The Armour Laboratories are now able to supply sterile'solutions in $5 \mathrm{cc}$. rubber capped vials of:-

The 1. "Glanoid"' Polyansyn

Armour (Polyvalent Extract) conLaboratories. taining all the hormones of the anterior lobe of the bovine pituitary gland including the thyrotropic and gonadotropic hormones. Assayed potency $\mathbf{5 0}$ growth units per cc.

2. "Glanoid " Growth Factor, indispensible to body growth. Assayed potency 100 growth units per cc.

3. "Glanoid " Maturity Factors, (Gonadotropic) essential to reproduction. Assayed potency 100 units per cc.

4. "Glanoid" Prolactin (Lactogenic Factor) producing functional activity of the mammary glands at the time of parturition. Assayed potency 100 Prolactin units (Riddle) per cc.

5. "Glanoid " Thyrotropic Factor, necessary for proper development and function of the Thyroid Gland. Assayed potency 50 thyrotropic units per cc.

6. "Glanoid" Adrenotropic Factor, governing the activities of the adrenal cortical tissue. Assayed potency 10 Adrenotropic units per cc.

It should be borne in mind that the application of the various anterior pituitary factors is replacement therapy as far as the pituitary gland is concerned but stimulation therapy to the male and female gonads, the thyroid and the adrenals.
The Pituitary factors in general are sensitive to heat. This is due to the proteinlike nature of some of the hormones. For this reason the solutions should not be exposed to heat. While the intramuscular administration of the various Pituitary factors is safe, intravenous injection is not recommended.

It is pointed out that the various factors presented are obtained from the anterior lobe of the Pituitary gland only, and should not be confused with the anterior pituitarylike preparations.

A brochure giving full details of the series, together with particulars of standardisation dosage and methods of administration, can be obtained from, The Armour Laboratories (Armour \& Company Ltd.) Armour House, St. Martins-le-Grand, London, E.C.1.

Although it seems early to think of hay fields, we have been reminded of such
Antibody

Products

Ltd. things by a pamphlet received from the laboratories of Antibody Products Limited regarding their "British Grass Pollen" treatment for hay fever.

From this pamphlet it would seem that the above laboratory have evolved a most simple means of test and treatment for the use of Practitioners who have patients suffering from hay fever.

The preliminary test is carried out by means of a neat scratch test set consisting 